\title{
Styring af straffastsættelsen med domsbaser - Anklagemyndighedens Vidensbase ${ }^{1}$
}

\author{
Af Rasmus H. Wandall ${ }^{2}$
}

»The idea of providing far better, more complete, faster information to lawyers, judges, scholars and reformers may be the most attractive sentencing reform model at all« (Miller 2004, 147-148)

\begin{abstract}
This article discusses the knowledge base of the Danish Prosecution Service and its guidance of criminal sentencing decision-making in Denmark. Important questions of the construction of sentencing practice information systems are discussed. These concern the ideal of formal consistency, a balance between vertical and horizontal governance, the legal criteria upon which to construct a sentencing database, the relationship between sentencing databases and formal guidelines, and where organisationally to place the administration of a sentencing database. Most importantly, the article argues that the construction of future databases should take its point of departure in the everyday information needs of practising lawyers, prosecutors and judges, and should include first instance case law, something that existing authoritative case collection consistently avoids. Furthermore, it is argued that the court system itself takes a lead role in the building of future sentencing databases.
\end{abstract}

\section{Indledning}

Artiklen redegør for udviklingen af den danske anklagemyndigheds vidensbase, herunder særligt dens domsbaser, og diskuterer anvendelsen af domsbaser som et praktisk middel til at sikre større retlig ensartethed og generelt højere retligt niveau ved straffastsættelsen i straffesager. Efter en indledende gennemgang af gængse problemstillinger ved regulering af straffens fastsættelse gennem systematisering af retspraksis, gennemgår artiklen kort de vigtigste eksisterende praksisbaser i Danmark. På den baggrund rapporterer artiklen anklagemyndighedens

* Title in English: „Governing criminal sentencing through sentencing information systems.

- The knowledge system of the Prosecution Service«. 
udvikling af en landsdækkende web-baseret vidensbase blandt andet indeholdende praksis. Med afsæt i disse erfaringer diskuteres en række udfordringer for eksisterende og fremtidige baser.

I de seneste årtier er adskillige nye og gamle teknikker til styring af straffens fastsættelse i alle nordiske lande. Mest fremtrædende i faglige diskussioner er minimumsstraffen. I Danmark er det nok den øgede anvendelse af forarbejder til at styre straffeniveauet inden for strafferammerne, som er af størst reel betydning. Inden for visse sagsområder kan man i dag i forarbejder finde ganske præcise angivelser af, hvordan straffen skal fastsættes. ${ }^{3}$ Straffelovrådet har således også siden 2009 arbejdet med spørgsmålet om, hvordan lovgiver kan regulere straffens fastsættelse, herunder hvordan lovgiver kan kommunikere om straffastsættelse til domstolene. Se Justitsministeriet (2009) samt den ny færdige betænkning 1531/2012. Se tilsvarende den tidligere Nordisk Strafferetskomités betenkning NU 1984:2. Hertil kommer, at Rigsadvokatens meddelelser, som indeholder et omfattende reguleringsredskab inden for mange praktisk relevante områder, siden 1995 har udgjort et væsentligt supplement til forarbejdernes regulering, og derved i mange år været et naturligt redskab for alle retsanvendere inden for strafferetten.

Denne udvikling til trods står retternes egen praksis fremdeles centralt i den stadige fastlæggelse og udvikling af straffeniveauerne. Alle dommere, anklagere og forsvarere kan genkende spørgsmålet: »hvad plejer man at gøre i lignende sager«. Uden detaljerede regler på de fleste områder, og med fastholdelsen af en tradition, hvor hver sag er konkret, er det naturligt at søge i domstolenes egen praksis efter svaret på det spørgsmål. Det er her, at problemstillingen for nærværende artikel giver sig til kende: Som på alle andre retlige områder er skønnet ved straffens fastsættelse ikke tomt, men genstand for normativ styring, hvorigennem et niveau af formel retlig ensartethed kan opnås. I det danske strafferammesystem er det domstolenes egen praksis, som er vigtigst. Problemet er, at retsanvendere advokater, anklagere og dommere - kontinuerligt mangler adgang til relevant retspraksis, og dermed mangler et centralt normativt redskab til at sikre et niveau af formel ensartethed. Problemet er manglende effektiv adgang til relevant viden. Knud Waaben $(2001,100)$ skrev, at »i et lille land med meget fri appelmulighed vil tvivlsspørgsmål om udmålingsniveauet blive afklaret gennem appelretternes praxis«. Man kan måske omformulere det således, at i et lille land med kun to landsretter og med et højt uddannelsesniveau og et stærkt fagligt fællesskab blandt retsanvenderne, vil retsanvenderne gennem interaktion inden for og i mellem institutioner, finder nogenlunde det samme niveau. Men det er ikke en formel holdbar situation. Hverken for den enkelte borger eller for retssystemets udvikling. Problemet er godt eksemplificeret i de mange private samlinger af domme 
og praksisoversigter, som anklagere, forsvarere og dommere administrerer, for at kunne besvare spørgsmålet »hvad plejer man at gøre i lignende sager«. De fleste praktikere samler således løbende eksempler på domme og kendelser i både almindelige og specielle sager, og opbevarer dem til brug i senere sager. Samlingerne svinger fra usorterede bunker af papir til alfabetisk sorterede mapper og emnemæssigt systematiserede reolsystemer med tusindvis af praksis-eksempler. Mange af samlingerne er eminente arbejdsredskaber. Problemet med samlingerne er imidlertid, at der ikke er to, som er ens, og at de oftest ikke opdateres løbende i forhold til retsudviklingen. Selvom samlingerne er gode og naturlige arbejdsredskaber, er de samtidig et symptom på et underskud af fælles informationsredskaber til fastsættelsen af straffen. Og hvor der mangler fælles redskaber, træder lokale og uformelle - og uigennemsigtige - redskaber let i stedet.

Det spørgsmål, som melder sig, er, hvordan man kan organisere og gøre relevant viden om praksis om det almindelige straffeniveau tilgængelig og dermed give retsanvendere et fælles normativt redskab til at sikre et acceptabelt niveau af retlig validitet og formel ensartethed? Teoretisk er spørgsmålet indlysende. Retspolitisk er spørgsmålet aktuelt, og praktisk efterlyses bedre adgang til nødvendige arbejdsredskaber, for at kunne leve op til de stadigt stigende krav til rettens anvendelse.

\section{Eksisterende praksissamlinger og -oversigter}

Der findes mange systematiske samlinger af retspraksis, både på tværs af fagområder og inden for specialiserede fagområder. Det ligger uden for denne fremstilling at gennemgå dem alle. Jeg vil fokusere på de for straffesagsbehandlingen mest centrale, Ugeskrift for Retsvaesen (UfR) og Tidsskrift for Kriminalret (TfK). Begge offentliggør udvalgte domme fra landets landsretter og Højesteret. Ugeskrift for retsvaesen er udgivet siden 1867 og har, i særdeleshed efter at de elektroniske udgaver er kommet til, skabt et vigtigt praktisk redskab for retsanvendere. Tidsskrift for Kriminalret er blevet udgivet siden $1999 \mathrm{og}$ har skabt et betydeligt bredere praksisgrundlag i straffesager. Dommene og kendelserne i begge tidsskrifter er udvalgt af fagredaktører. Derudover udgiver foreningen af beskikkede forsvarsadvokater et tidsskrift, Meddelelser fra foreningen af beskikkede advokater, som indeholder udvalgte relevante dokumenter samt udvalgte domme og kendelser fra alle tre retsinstanser. Tidsskriftet udgives med let anvendelige registre. Dommerforeningen har i en årrække samlet domsoversigter - og andre praktiske beskrivelser og oversigter - i nogle ringbind. Domsoversigterne dækker kun udvalgte retsområder, men giver adgang til praktisk let anvendelige oversigter for disse retsområder. F.eks. vil alle strafferetsanvendere i Danmark være bekendt 
med oversigten over domme i narkotikasager samt den for socialbedrageri. Der er flere andre. Fælles for dem er, at de fokuserer på de øvre retter, men i vid udstrækning også er beskrivende for retspraksis ved byretterne også. Domsoversigterne vedligeholdes ikke systematisk, og mange af de konkrete oversigter er således af ældre dato. Hertil kommer Domme i kriminelle sager, som blandt andet samler de gennem Forlaget Karnov Group Denmark A/S offentliggjorte domme i en større systematisk oversigt. Den første udgave publiceredes i 1876 med et systematisk register. De mange senere udgaver repræsenterer en stadig større nuancering og udvidelse af såvel indhold som systematisk register. Den seneste udgave, som samler domsoversigterne for 2008-2010, er på 788 sider, og er således et større værk. Det er i dag et naturligt redskab i straffesager i landets retskredse.

Udover disse samlinger findes der domsoversigter, som udarbejdes ad hoc. For eksempel udgav Direktoratet for Kriminalforsorgen en større samling af domme vedrørende anvendelsen af samfundstjeneste i forlængelse af indførelsen af denne sanktionsform. Rigsadvokaten udgiver jævnligt domsoversigter for udvalgte områder i forlængelse af eksisterende indberetningsordninger og redegørelser til Justitsministeriet og Folketinget. Se nærmere på www.rigsadvokaten.dk. Disse til tider sporadiske domssamlinger udgør alle vigtige redskaber for retsanvendere.

Jeg vil i det følgende koncentrere mig om samlingerne i UfR og TfK. Begge udgiver lands- og Højesteretspraksis, men ikke byretspraksis. Udgivelserne er på denne måde i overensstemmelse med den hierarkiske orden i retspraksis. Der er såvel teoretisk som praktisk indbygget en vertikal styring af straffeniveauet igennem den retspraksis, som gøres tilgængelig. Det er her meningen, at byretterne skal styres af Landsretterne og Højesteret, ikke at byretterne skal styre hinanden. Denne strategi har den gode konsekvens, at domssamlingerne har en tæt sammenhæng med strafferettens dogmatiske udvikling. Men strategien har også et iboende og ubesvaret problem: Samlingerne indeholder for mange fagområders vedkommende ikke den praksis, som retsanvendere har brug for i deres daglige arbejde. Det skyldes, at den retspraksis, som angiver det almindelige og normale sanktionsniveau, i vid udstrækning findes i byretterne og i politi- og anklagemyndigheden, men kun i mindre udstrækning kommer til landsretterne og kun sjældent til Højesteret. Det gælder både almindelige afgørelser inden for de fleste sagsområder, og det gælder hele sagsområder, som kun sjældent kommer for landsretterne. I 2010 blev der afsluttet 153.999 straffesager ved landets byretter. Samme år blev der afsluttet 6.552 straffesager ved landets to landsretter. Af disse er under 600 publiceret i TfK og i UfR. Når samtidig henses til, at retsplejeloven kun tillader anke uden procesbevillingsnævnets tilladelse i begrænset omfang, vil 
der i det hele naturligt være en stærk underrepræsentation af normale byretssager ved de øvre retter. ${ }^{4}$ Særligt for sager af mindre størrelse vil der naturligt være en stærk underrepræsentation, og dermed ikke et tilstrækkeligt vidensgrundlag til at lede retsanvendelse ved byretterne. Hertil kommer et mere subjektivt indtryk, som jeg nok ikke har empirisk grundlag for at udtrykke, men ikke desto mindre vil påstå er sandt. Udvælgelsen af landsretsafgørelser til de trykte samlinger fokuserer, af både saglige og traditionelle grunde, først og fremmest på de afgørelser, som afprøver retlige grænser med videre og repræsenterer dermed snarere de $u$ almindelige end $a$ lmindelige afgørelser. Det gælder UfR i større grad end TfK. Denne strategi bidrager til en tæt sammenhæng mellem samlingerne og strafferettens dogmatiske udvikling, men betyder samtidig, at samlingerne er mindre velegnede til at besvare spørgsmålet »hvad plejer man at gøre? «i de almindelige sager, der er flest af ved retterne.

Selvom de supplerende domssamlinger bidrager væsentligt til kommunikation af almindelig retspraksis, er den praktiske virkelighed, at den enkelte retsanvender $i$ almindelige straffesager ved landets byretter i vid udstrækning ikke er udstyret med viden om straffeniveauerne i ganske almindelige straffesager. Det er i det lys, at man skal forstå, hvorfor alle retsanvendere har en eller anden form for privat visdomssamling, og hvorfor mange embeder har medarbejdere, som er dedikerede til at samle relevant praksis-viden til embedets medarbejdere. Der findes således to niveauer af viden om retspraksis om strafudmåling i Danmark. Dels de trykte og landsdækkende samlinger, dels de lokale og private samlinger, hvis indhold de færreste kender til, og som må formodes at adskille sig fra hinanden.

Blandt de mange problemstillinger, som anklagemyndighedens medarbejdere ønskede at løse efter den danske politireform i 2007, var dette et af dem: At kunne dele den store viden, herunder om straffens fastsættelse, som landets embeder og medarbejdere ligger inde med. Anklagemyndighedens vidensbase er en af de praktiske løsninger på den problemstilling.

\section{Anklagemyndighedens vidensbase}

Siden 2008 har anklagemyndighedens medarbejdere haft adgang til en vidensbase indeholdende alle interne forskrifter, herunder Rigsadvokatens Meddelelser (RM) og Rigsadvokaten Informerer (RI), instrukser, redegørelser, vejledningsmateriale, praksisoversigter, samt en ny og stadigt voksende samling af praksisbaser. Hertil kommer løbende nye former for vidensredskaber til mødende anklagere. ${ }^{5}$ Essensen af vidensbasen er, at hver enkelt medarbejder fra sin arbejdsplads via intranettet (det interne web) ved ganske få søgehandlinger kan fremfinde retligt relevant materiale til en sags forberedelse og gennemførelse. Materialet kan prin- 
tes og anvendes direkte i retten. I en sag, hvor der er spørgsmål om udvisning af en indbrudstyv til Rumænien, vil en medarbejder kunne indtaste simple søgeord (f.eks. »tyveri indbrud udvisning «) i vidensbasen og få direkte adgang til de relevante forskrifter og praksiseksempler til sagens forberedelse. Der er tillige etableret en kobling til Karnov Groups produkter, således at anklagere med en enkelt søgning $\mathrm{i}$ vidensbasen også făr direkte adgang til de tilsvarende resultater i Karnov, TfK og UfR. ${ }^{6}$ Vidensbasen er endvidere konstrueret til også at formidle navne og kontaktinformationer på kolleger med en særlig viden inden for de søgte emner. ${ }^{7}$ Pr. 25. januar 2011 var der 2.596 domme, kendelser og administrative afgørelser i baserne, som alle medarbejdere kan søge frit i.

Basen udbyder retspraksis inden for en række fagområder af praktisk betydning. Det drejer sig om følgende:

- Narkotika

- Røveri

- Vold og trusler $(\S \S 119,121, \S 247$, stk. 2)

- Bedrageri

- Mandatsvig

- Dyreværn

- Erstatning inden for strafferetsplejen

- Indgreb i meddelelseshemmeligheden

- Ransagning

- Edition

- Udvisning inden for EU

- Politiets virksomhed uden for strafferetsplejen (Politiloven og Våbenloven foreløbeligt to sagsområder)

Som en naturlig afspejling af det praktiske behov dækker vidensbasen, udover spørgsmål om straffens fastsættelse, også en række andre spørgsmål, herunder straffeprocessuelle og forvaltningsretlige spørgsmål. I det følgende fokuserer jeg på basernes indhold vedrørende straffens fastsættelse.

For hvert sagsområde indeholder vidensbasen ny retspraksis, som eksemplificerer normalstraffen i en normal sag. Hvert sagsområde er emnemæssigt underopdelt i gerningskategorier. Inden for hver af gerningskategorierne findes to til fem eksempler på normal straffastsættelse. ${ }^{8}$ For eksempel er bedrageri underopdelt i data/forsikring/kredit/social/samhandel/andet og herunder i et antal beskrivende beløbsstørrelser. Hver dom er udstyret med en unik titel (f.eks. AM2010.02.03V) samt en stikordstitel, som passer ind i og forlænger emnestruk- 
turen, og derved gør det væsentligt lettere for brugeren allerede ud fra oversigtslisten (resultatlisten) efter søgning i vidensbasen at vurdere, om dommen er anvendelig. F.eks. inden for socialbedrageri er titlen for dom AM2011.01.12B4 »Akassebedrageri, uberettiget modtaget dagpenge, opnået vinding ca. 175.000 kr., 6 mdr. bet, pt. 1 år, 120 t. samf. tj., tilsyn.« Hver dom består af en kopi af den originale og anonymiserede dom. Den bærende ide er, at der inden for alle meningsfyldte emnekategorier findes to eller flere eksempler på normal straffastsættelse. Dommene er anonymiserede, kan printes direkte og indeholder en forside med summariske oplysninger samt titellinje på hver side.

\subsection{Udvcelgelse af domme og vedligeholdelse af domsbaserne}

Vidensbasen indeholder Højesteretsdomme, landsretsdomme samt byretsdomme. For Højesteretsdomme gælder det særligt, at alle afsagte domme, inklusive tidligere instansers afgørelser, lægges ind i basen og gøres tilgængelige inden for 24 timer efter afsagt dom. Det er den mødende anklager, som udvælger retspraksis til vidensbasen. Kriteriet for at udvælge en dom eller kendelse er, at den er retvisende for en normal håndtering af sagen i retten. I manualen for vedligeholdelse af narkotika-basen hedder det f.eks.:

\section{»Den ideelle dom}

Formålet med basen er at stille domme med eksempler på normalstraffe til rådighed. Den enkelte dom skal ideelt set:

- kun indeholde en enkelt stofart med betydning for straffastsættelsen.

- ikke indeholde anden kriminalitet af betydning for straffastsættelsen.

- være ny og fra dette eller sidste år. Dette gælder dog ikke for domme inden for særlige sagstyper, som kun forefindes sjældent, f.eks. besiddelse af råopium eller LSD.

- have resulteret i en normalstraf for den pågældende type sag.«

I alle sagsområder findes der domme, som er både lidt under og lidt over, hvad praktikere anser for normalen. Velvidende at der ikke findes en entydig normalstraf, er det afgørende at tilvejebringe eksempler, som dels identificerer et vejledende normalområde for straffens fastsættelse, dels fastholder, at retsanvenderen foretager en konkret vurdering af den foreliggende sag.

Den normale proces for udvælgelsen af en retsafgørelse (herefter »dommen«) til basen er, at den mødende anklager vurderer, at den er velegnet. Han eller hun angiver på sagens omslag, at dommen skal til vidensbasen og udfylder en blanket med emneord, titel og andre summariske oplysninger. Dommen sendes, typisk efter at embedets vidensansvarlige har gennemgået de udvalgte domme, til Rigs- 
advokaten. Rigsadvokaten anonymiserer dommen, indtaster emneord, titel med videre og klargør dommen til web-udgivelse. Dommen lægges på webbet klar til udgivelse. Et antal redaktører (typisk advokaturchefer eller senioranklagere) tager herefter stilling til, om dommen er retvisende, og om den tilfører nyt til vidensbasens allerede bestående praksisbaser. Redaktørerne kan læse og godkende direkte på deres computere, og dommen udgives automatisk i vidensbasen efter godkendelse. I tilfælde af afvisning sendes den automatisk tilbage til Rigsadvokaten. Den gennemsnitlige frasorteringsprocent i 2011 var $14 \%$. Frasorteringen er reelt nok større, idet der fra initial udvælgelse til den endelige redaktionelle godkendelse sker en frasortering på flere stadier.

Domsbaserne er dynamiske. I modsætning til UfR og TfK bliver domme og kendelser, som er uddaterede, fjernet fra basen med jævne mellemrum. ${ }^{9}$ Det er fagredaktørernes og fagudvalgenes ansvar at sørge herfor. Pointen med basens dynamik er ikke at fratage brugeren pligten til selv at tage stilling til retskildens anvendelighed. Pointen er, at der som udgangspunkt kun ligger ny og relevant praksis i basen, og at basen afspejler den stadige retsudvikling.

Der er hos Rigsadvokaten lavet et administrativt set-up til at kunne klare indsendelse af ca. 1000 nye retsafgørelser til basen om året. Derudover lægges der løbende afgørelser af principiel betydning ind i basen, herunder alle Højesteretsdomme, som sammen med Rigsadvokatens materialesamling og procedure til sagen, gøres tilgængelige i vidensbasen.

\subsection{Domsbasernes opbygning og driftsorganisering}

Hver base med retspraksis er baseret på en bruttosamling med retspraksis indhentet fra alle embeder. Der er typisk mellem flere hundrede og mere end tusinde afgørelser i samlingen. En ad hoc arbejdsgruppe bestående af eksperter fra de lokale anklagemyndigheder, statsadvokaterne samt fra Rigsadvokaten udvælger og gennemgår afgørelserne. På den baggrund udarbejdes der med udgangspunkt i den overordnede emnestruktur en mere detaljeret emnetaksonomi for sagsområdet. Herefter gennemgås sagerne igen med henblik på, at alle praktiske sagskategorier og underkategorier er repræsenteret med et antal domme.

For hvert nyt sagsområde defineres et forventet årligt antal domme til indsendelse til vidensbasen for hvert embede. Antallet er baseret på det forventede samlede antal nye domme i basen hvert år, fordelt på embederne efter deres andel rejste tiltaler inden for det pågældende sagsområde. Der udsendes hvert kvartal en oversigt over embedernes indsendte afgørelser, ligesom Rigsadvokaten rutinemæssigt følger op herpå i anklagemyndighedens faglige ledelsesforum samt i de relevante fagudvalg. Der er altså en fast forankring af basens vedligeholdelse i 
embedernes og organisationens ledelse. Formålet er dels at sikre løbende indsendelse, dels at sikre geografisk repræsentativ spredning. Organiseringen af den faktiske indsamling af retspraksis sker lokalt ved de enkelte embeder. ${ }^{10}$

På landsplan er de mange sagsområder fordelt på fem fagudvalg (personfarlig, økonomisk, særlov, organiseret, erstatning). Hvert fagudvalg har ansvaret for at praksissamlingerne inden for deres område vedligeholdes. De ansvarlige redaktører refererer således til fagudvalgene, og fagudvalgene tager årligt stilling til samlingernes tilstand. Det har således fra begyndelsen været en fast holdning, at hvis en domsbase ikke vedligeholdes med løbende ny og relevant praksis, skal den lukkes ned. Dette står i kontrast til andre eksisterende praksisbaser.

Som led i anklagemyndighedens årlige målsætninger finder der hvert efterår en proces sted, hvorigennem fagudvalgene og embederne tager stilling til, hvilke nye sagsområder, der - om nogen - skal udvikles. Resultatet er en brutto-liste, hvorfra Rigsadvokaten udvælger et antal til udvikling.

\section{Problemstillinger}

Anvendelsen af domsbaser rejser en række principielle og praktiske problemstillinger for tilsvarende baser og redskaber, i Norden såvel som i andre jurisdiktioner. Det er indlysende, at sådanne overvejelsers konkrete formulering og løsning varierer med det retlige system, det politiske system, såvel som med den retlige og pønale tradition og udvikling landene i mellem. Ikke desto mindre er der nogle problemstillinger, vis generelle karakter kan genkendes på tværs af de nordiske grænser, og givetvis også videre i andre lande. I det følgende vil jeg, med udgangspunkt i ovenstående beskrivelser, gennemgå og diskutere nogle af dem, som er af stor betydning.

\subsection{Skaber domsbaserne større formel ensartethed?}

Det første spørgsmål, som de fleste domsbaser bliver mødt med, er: Virker basen til at skabe større formel ensartethed i retsanvendelsen? Der foreligger en del empirisk belæg for påstanden om, at formelle guidelines af en vis præcisionsgrad virker til at skabe større formel ensartethed i jurisdiktioner, hvor der er en udtalt mangel på retspraksis og anden alternativ normativ vejledning (Ostrom et al 2008). Der findes imidlertid ikke forfatteren bekendt nogen evidens for påstanden om, at domssamlinger eller -baser virker til at skabe større formel ensartethed, hverken i jurisdiktioner med mangel på vejledning eller i jurisdiktioner som de nordiske, hvor der er en langvarig tradition for at anvende retspraksis. Der foreligger heller ikke evidens for det modsatte. Der har ellers i mange lande været foretaget en del forsøg med sådanne systemer. De manglende effekt-målinger hæn- 
ger sammen med, at det ikke har været hovedprioriteten at måle effekten af systemerne, samt med, at det er vanskeligt at måle ensartethed, når det er en del af den retlige konstruktion, at retsanvenderen har et betydeligt rum til at foretage en konkret vurdering. Men måske er spørgsmålet slet ikke det rette at stille. I lande med højt professionaliserede anklagere, advokater og dommere, hvor der allerede eksisterer en rig tradition for formel retsanvendelse, og hvor standarderne for straffastsættelse slet ikke lægger op til en rigid ensartethed i straffastsættelsen, er målet i mindre grad at skabe en urokkelig og kategorisk straffastsættelse. Målet er snarere at skabe et højt retligt bevidsthedsniveau og herigennem få retsanvendere til at anvende ensartede metoder og operere inden for samme normative rammer. ${ }^{11}$ Det kan så til gengæld være befordrende for ensartethed i sagens behandling. Dette mål kan forhåbentlig være med til at skabe fælles retlige standarder på en sådan måde, at der samtidig tillades den sagsbestemte tilpasning, som sagernes karakter og behandling fordrer. Det er en målsætning, som - med retsanvenderen i centrum - lever på forudsætningen om, at al effektiv regulering hviler på en bæredygtig balance mellem skøn og regel og en balance mellem central regulering og lokal tilpasning. Det er således også karakteristisk for den dynamiske udvikling af vidensbasens indhold, at den stammer fra kredsene og de regionale anklagere selv.

Realiserer anklagemyndighedens vidensbase målsætningen? Det spørgsmål må besvares i de kommende år. Basen har ikke eksisteret i lang tid, og i en periode med meget store omvæltninger $\mathrm{i}$ anklagemyndigheden er det vanskeligt at konkludere noget ud fra en mål-effekt undersøgelse. Det har derfor heller ikke været en del af projektets indledende fase. Skal man i den kommende tid måle på, om den virker efter hensigten, vil man i det mindste skulle måle på følgende tre indbyrdes forskellige parametre: 1) praktikernes søgning efter retspraksis og anden relevant viden, 2) faktisk anvendelse af retspraksis til sagens forberedelse og behandling, 3) faktisk inddragelse af retspraksis i rettens behandling af sagen. Hvert parameter kan måles på en række forskellige indikatorer og repræsenterer en række metodiske udfordringer.

Hvad kan man forvente? Der er en række allerede kendte forhold, som må antages at bidrage til at nå målet med en domsbase. F.eks. at der er en stærk forankring i og sammenhæng med allerede eksisterende og legitime retskilder (Hutton et al 1994), at hver domsbase er fast forankret i brugeres kendte praktiske behov i straffesager, og at der er en tæt identitet mellem brugere og domsbasernes indhold. Forankring og drift er i vid udstrækning henlagt til de lokale anklagemyndigheder således, at mødende anklagere både er skabere og brugere af domsbaserne. Men retligheden af retsafgørelser sikres jo som bekendt gennem en daglig 
interaktion i retten og er et produkt af en lang række yderligere begivenheder i anklagemyndigheden, ved retterne og hos advokaterne. En bedre adgang til viden er således ingenlunde nok. Målopfyldelse er afhængig af, om der er en tilstrækkelig uddannelsespraksis, om der er en ledelseskultur i den lokale anklagemyndighed, som ansporer til en høj - og passende - retlig kvalitet i den daglige sagsbehandling, og af om de formelle og uformelle mentorer lærer de nye anklagere at anvende domsbaserne. Dertil kommer, at der blandt dommere er behov for en forventning til anklageren om niveauet af den retlige forberedelse, samt til hvilken dokumentation af retspraksis, som forventes at finde sted. Der er altså organisatoriske og uddannelsesmæssige spørgsmål, som udover tilgængeligheden af den retlige viden, spiller en afgørende rolle.

\subsection{Vertikal og horisontal styring}

Domsbaser må, ligesom al anden retlig regulering, finde en balance mellem vertikal (hierarkisk) og horisontal styring. Bliver reguleringen for koncentreret i toppen (for vertikal), eller bliver reguleringen overladt for meget til retsanvendernes egen kommunikation på tværs (for horisontal), mister reguleringen værdi og effekt. En balance er nødvendig.

Udtalt vertikal styring kendes for eksempel fra straffelovens $\S 192$ a om minimumsstraf på 1 år for besiddelse af visse våben under særligt skærpende omstændigheder, fra principielle højesteretsdomme, samt fra mange af retningslinjerne i Rigsadvokatens meddelelser. Vertikal styring er attråværdig, blandt andet fordi den har en stærk sammenhæng med retssystemets hierarkiske struktur og herigennem bidrager til at sikre retsstatens ideal om formel retsenhed. Udtalt vertikal styring er dog ikke uden problemer. For det første er der ikke ved landets øverste myndigheder kapacitet til at regulere tilstrækkeligt tæt på alle områder. Mange områder efterlades derfor de facto til lokal sædvanedannelse. For det andet skabes der på de områder, hvor der faktisk reguleres, en betydelig afstand mellem reguleringen - hvad enten det er lovgiver, Højesteret eller Rigsadvokaten - og så den konkrete retsanvendelse. Dette følger af sagens natur, da retsanvendelse er mere end blind regel-efterlevelse, og også nødvendigvis vil forholde sig til de substantielle problemstillinger, som en sag repræsenterer. Udtalt vertikal regulering er blind for disse omstændigheder, nyder mindre legitimitet og ansporer til konkurrerende lokal normdannelse. Dette er mekanismer, som er velkendte i de mange jurisdiktioner, som i de sidste årtier har implementeret stærkt vertikale styreformer - mest udtalt jurisdiktioner i De Forenede Amerikanske Stater samt i England og Wales (Tonry 1996; 2001). 
Udtalt horisontal styring ser vi, når retsanvendere lader sig styre af praksis fra kollegiale institutioner. Dyden ved horisontal styring består i, at den er tættere på den konkrete retsanvendelse og således giver plads til de lokale og konkrete tilpasninger, som forholdene kræver. Der vil nok kunne identificeres en formel ensartethed, men den udspringer af en løbende dialog med konkrete praksis-behov. Der vil blive sikret en større bredde i reguleringen - det vil f.eks. ikke kun være narkotika-eksempler fra København og Odense, men også fra Sønderborg og Holstebro, som bidrager til normeringen af en normalstraf. Et andet aspekt af horisontal styring består $i$, at den synliggør og inddrager den variation, som findes $i$ landet, i stedet for at vende det blinde øje til. Se også Miller $(2004,137)$. Det betyder nemlig, at vi overhovedet făr mulighed for at se og reagere på den variation, som findes. Problemet med horisontal styring er, at der mangler et retsstatsligt mandat til at fastlægge den eller de normer, som er den eller de korrekte. I stedet bliver det en standard, hvor der nok er en forbindelse mellem normen, og hvad der er retligt korrekt, men det er uklart, om det er standarden i København, Århus, Esbjerg eller Næstved, som er den styrende. Det er et retsstatsligt problem, som netop den vertikale styring kan afhjælpe.

Anklagemyndighedens vidensbase kombinerer disse vertikale og horisontale aspekter af retlig regulering gennem valget af retspraksis og gennem organiseringen af selve udvælgelsesprocessen af de konkrete domme. Det blev hurtigt besluttet, at ikke kun Højesterets og landsretternes afgørelser, men også byretternes kendelser og domme, skulle indgå i vidensbasen. Det var således mødende anklageres klare ønske at få adgang til almindelig byretspraksis, som viser, hvordan man normalt gør i lignende sager. Det betyder, at der i dag er ca. 150 højesteretsafgørelser, 740 landsretsafgørelser og 1.700 byretsafgørelser. Fra et ledelsesmæssigt perspektiv var det afgørende ved dette valg, at det kun er med byretternes afgørelser, at vidensbasen ville kunne opnå en landsdækkende repræsentativitet i en lang række almindelige sager, som behandles ved retterne. Alternativet ville efterlade store huller i dækningen. For så vidt angår sorteringen og godkendelsen af de domme, som skal indgå i domsbaserne, var der flere forskellige muligheder. For det første kunne godkendelse lægges i kredsene. Dette ville afstedkomme en udtalt horisontal styring og en svækket retlig ensartethed. En anden mulighed var at lægge godkendelsen hos statsadvokaturerne, som i forvejen gennemgår mange sager i forbindelse med ankespørgsmål og tilsynsvirksomhed. Det ville sikre større hierarkisk styring, men ville også lægge en vigtig del af konstruktionen i en embedsstruktur, som var under forberedelse til at blive stærkt forandret (jf. den nu færdige betænkning nr. 1523/2010 og lovforslag nr. 40, fremsat den 23. november 2011). En tredje mulighed var at lade Rigsadvokaten godkende hvilke 
domme, som skal i vidensbasen. Det ville skabe kontinuitet til de allerede eksisterende domsoversigter, som findes inden for anklagemyndigheden. Problemet med denne løsning er, at den dels ville skabe den afstand til retsanvendelse, som netop ønskedes undgået, og at det ville skabe en organisatorisk flaskehals, som ville begrænse det antal domme, som ville blive lagt ind, og dermed den horisontale dækning og kvalitet. Valget faldt derfor på en kombination i form af en helt fjerde mulighed - at lægge ansvaret for godkendelse i permanente redaktionsgrupper oprettet under de landsdækkende fagudvalg, som eksisterer inden for hver af de faglige hovedområder. F.eks. er der en redaktionsgruppe inden for fagområdet organiseret kriminalitet, som nu har ansvaret for, at domme godkendes eller afvises, og som i det hele taget har ansvaret for, at de domme, som lægges i vidensbasen inden for det pågældende fagområde, er retvisende. Den yderligere gevinst ved disse redaktionsgrupper er, at medlemmerne er faglige eksperter, som samtidig er tæt på den konkrete retsanvendelse, og derfor også er godt placeret til at vurdere, om dommene modsvarer et praktisk behov.

Resultatet var således en model med en solid horisontal styring fra kredsene, kombineret med en vertikal styring gennem landsdækkende redaktionsgrupper. Til at danne en funktionel ramme om denne formelle konstruktion fungerer Rigsadvokaten som administrativ understøttelse og i sidste instans ledelsesmæssig garant for vidensbasens funktionalitet. Sidstnævnte sker igennem anklagemyndighedens ledelsesfora.

Lægger man disse iagttagelser ned over den eksisterende praksisdækning i TfK og UfR, ser det ud til, at begge er stærke i vertikal styring, men samtidig, at de ikke forfølger nogen nævneværdig balance med horisontal styring. Resultatet er sagsområder, hvor der ingen vejledning findes, og en til tider total blindhed for de lokale variationer, som eksisterer. Omvendt er dommerforeningens domssamlinger stærke i deres horisontale styring. Samlingerne har den naturlige autoritet, som følger af, at det er dommere, som udvirker dem, men ikke desto mindre mangler der hierarkisk styring. Udviklingen af fremtidige praksissamlinger og domsbaser bør ske i retning af større dækning og inddragelse af byretternes praksis i en kombination med en eller anden form for praktiserbar hierarkisk styring. Vil en sådan øget horisontal styring medføre en retlig pluralisme, som ikke hører hjemme i strafferetten og som i hvert fald er i strid med fordringen om retlig ensartethed i straffastsættelsen? Svaret er nej. For det første er der ikke noget nordisk land, hvis strafferet prædiker en så kategorisk og fintmasket ensartethed, at der ikke er plads til substantielle overvejelser og variationer på et konkret niveau og dermed også åbenhed for et vist niveau af normativ pluralisme. Det er uundgåeligt. For det andet introducerer en øget horisontal styring ikke en pluralisme i 
straffastsættelsen, som ikke er der i forvejen. Tværtimod. Ved at inddrage retspraksis på byretsniveau synliggøres den pluralisme, som måtte være der i forvejen, og tvinger den ind i et legitimt forhold til retspraksis i øvrigt. Man kan sige, at en øget horisontal styring i stedet for at vende det blinde øje til den pluralisme, som måtte eksistere, tager fordringen om en bæredygtig retlig ensartethed i straffastsættelsen seriøst.

\subsection{Er alle retligt relevante kriterier reprcesenteret?}

Hvilke retlige kriterier skal være styrende for straffastsættelsen? Spørgsmålet er relevant for enhver form for retlig regulering og således også ved designet af domsbaser. Man kan ikke forestille sig en domsbase uden struktur. Spørgsmålet er blot hvilken. Valget af kriterier hænger naturligt sammen med den strafferetlige ideologi, som forfølges, hvad enten det er generalprævention, individualprævention eller retfærdighedsbaserede teorier. De numeriske guideline-systemer i »U. S. Federal Sentencing Guidelines« og de nyere »Virginia Criminal Sentencing Guidelines« er gode eksempler på regulering, som følger en relativt stram gerningsbestemt ideologi og struktur. Se nærmere herom (Wandall 2006; Frase 2005).

I dansk ret fremhæver straffeloven både gerningsrelaterede og personrelaterede faktorers betydning ved straffens fastsættelse, jf. straffelovens $\S 80$. Selvom gerningsproportionalitet $\mathrm{i}$ teori og praksis fremhæves som det vigtigste udgangspunkt, repræsenterer systemet en kombination af individual- og generalpræventive idealer. Se f.eks. også Elholm (2010, 86-88), Greve (2002, 237-240), betænkning 1424/2002 (side 287) og betænkning 1099/1987 (side 67).

Anklagemyndighedens vidensbase afspejler denne virkelighed. Emnestrukturen er bygget op efter hovedforholdets art og herefter gerningens grovhed. De enkelte kategorier er gjort brede for at tillade en nødvendig konkretisering. De problemer med at identificere specifikke gerningselementer, som følger med en meget stram styret kategorisering, opstår ikke. Se f.eks. Hutton et al (1994) om det skotske system. Stikords-titlerne (se ovenfor afsnit 3) nuancerer dommens kendetegn i forlængelse af emnestrukturen, men således, at vigtige proces- og personrelaterede oplysninger også indgår. Samtidig tillader vidensbasen ustruktureret søgning og dermed mulighed for at brugeren kan gå på tværs af den formelle emnestruktur. Konkret vil det sige, at brugerne kan fritekstsøge efter forekomsten af ord eller dele af ord, som de måtte lede efter i konkrete retsafgørelser, uden at være bundet af den formelle emnestruktur. Det er også muligt at kombinere emnesøgning og fritekstsøgning. På flere måder supplerer vidensbasen således den gerningsbestemte emnestruktur med mulighed for at give plads til personlige og 
sociale oplysninger. Realiserer vidensbasen de retligt relevante kriterier for straffastsættelsen? Svaret er, at vidensbasens struktur er i overensstemmelse med den retlige struktur, og at den nok på lang sigt vil realisere den. Men svaret er også, at vidensbasens struktur forlader sig afgørende på, at retsanvenderen er kompetent og har den nødvendige indsigt til at anvende retspraksis.

Det lidt bredere spørgsmål er, i hvilken udstrækning dette er nok, og om fremtidige baser kan inddrage de forskelligartede retlige kriterier yderligere? Først og fremmest må man spørge, om ikke det er muligt at lade selve den formelle struktur afspejle gerningspersonens karakteristika direkte? Der findes flere eksempler på systemer, som gør det. Det skotske system SIS giver f.eks. dommere mulighed for at vælge domme ud fra kriterier så som køn, alder, tidligere straffe, og om der er indgået plea-agreement (Hutton et al 1994). Guideline systemet i staten Virginia i USA strukturerer valget af ubetinget fængsel efter oplysninger såsom alder, køn, fast arbejde, uddannelse og tidligere anholdelser (Wandall 2006). Man kunne i Danmark forestille sig, at en vidensbase inden for hvert sagsområde blandt andet tilvejebringer praksiseksempler på forskellige sanktioner for en person på 18 år, for en person på 25 år, for en person med uddannelse og nuværende arbejde og en person uden. En person i samlivsforhold og en person udenfor. Det ville være en måde at strukturere dommene på, som giver mere plads til de personlige forhold. De to afgørende spørgsmål er dog, om dette ville afspejle den vægtning af personoplysninger, som retspraksis tilsiger, og om en sådan standardisering af personoplysninger i det hele taget er ønskværdig. Sidstnævnte er i sidste ende et retspolitisk spørgsmål. I en dansk sammenhæng er der dog god grund til at fremhæve den stærke sammenhæng mellem dommerens konkrete skøn og personlige og sociale oplysninger, som har domineret strafferetten i moderne tid. En standardisering ville stå i kontrast hertil. Man kan argumentere for, at det ville virke til at få straffastsættelsen til at afspejle individualpræventive forhold i flere sager. Men heroverfor ville det også kunne anføres, at det ville formalisere og legetimere en indirekte og ulovlig forskelsbehandling på en række områder, f.eks. tilknytning til arbejdsmarkedet. Tilbage står, at en standardisering vil medføre en retlig stillingstagen til værdien af de mange enkelte aspekter af personlige og sociale oplysninger, som det nuværende system ikke lægger op til.

\subsection{Domsbasers rolle over for lovgivning, forarbejder og administrative forskrifter}

Domsbaser skal selvsagt virke inden for rammerne af gældende ret og dermed de love, som lovgiver vedtager. I praksis vil domstolene tilsvarende følge loves forarbejder og den vejledning, som findes deri. ${ }^{12}$ Man kan spørge, om der er behov 
for retspraksis og domsbaser på områder, hvor love og forarbejder og yderligere forskrifter i forvejen bidrager med nuanceret vejledning.

I anklagemyndigheden opstår situationen løbende. Når der skal vælges nye områder til domsbaser, er det af ressourcemæssige årsager naturligt at vælge områder, hvor der ikke i forvejen findes regulering, og hvor domsbaser er det bedst egnede redskab. Når lovændringer påkalder sig yderligere administrativ vejledning, er en cirkulæreskrivelse eller en instruks ofte det mest fordelagtige og praktiske redskab. Lige så ofte er det praktiske behov dog også at kommunikere til mødende anklagere, hvordan domstolene fortolker lovændringen, og hvilket niveau i straffastsættelsen domstolene lægger. I de tilfælde er en samling af domme den praktisk letteste og det mest effektive middel.

Fra en principiel synsvinkel ser det anderledes ud. Domstolenes centrale rolle i straffastsættelsen som den institution, hvis opgave det blandt andet er at skabe en konstruktiv og bæredygtig forbindelse mellem generelle regler og konkrete sager, gør, at retspraksis er nødvendig, ikke blot hvor lovgiver ikke har reguleret, men også hvor lovgiver har reguleret. Domstolenes praksis tjener til at udfylde skønnet i de mange konkrete situationer, som love finder anvendelse på, og tjener til at nuancere vejledende forslag i lovforarbejder. Men måske vigtigst tjener retspraksis til at nuancere og afbalancere lovens vejledning med den konkrete virkelighed, som konkrete straffesager byder på. Højesterets fortolkning af straffelovens $\S 192$ a, som udformet ved lov nr. 501 af 12. Juni 2009, er et godt eksempel herpå. Landsretternes mange domme, som fortolkede bestemmelsen samt fastlagde straffastsættelsesniveauet, afveg fra hinanden, indtil Højesteret ved en række afgørelser i al væsentlighed fastlagde bestemmelsens rækkevidde og straffastsættelsesniveauet. ${ }^{13}$ Dertil kommer, at en formidling af retspraksis er fordelagtig derved, at retsanvenderen kan se, at en given løsning ikke blot kan udledes af lovgivningen, men også er fundet legitim ved domstolene. I den praktiske magtfordeling er dette af nævneværdig betydning. Ud fra disse betragtninger er det vanskeligt at stille domsbaserne op som et alternativt valg til anden regulering. Det er snarere et nødvendigt supplement på alle områder. Det er en ressource, som beriger skrevne retskilder, gør dem stærkere hos retsanvenderen, og som udjævner den tvivl og variation, som ofte eksisterer retsanvendere imellem.

Eksisterende domsbaser, herunder UfR, TfK og anklagemyndighedens vidensbase, gør en del for at muliggøre denne kombination. Vidensbasen kæder forskrifter, praksisoversigter, retsafgørelser såvel som andre redskaber sammen inden for hvert eneste gerningsområde. Derudover har anklagemyndigheden udviklet en række nye dokumenttyper, som kobler forskrifter sammen med praksiserfaringer på en for brugeren praktisk let måde. Fremtidige initiativer skal gøre 
mere for at kombinere forskrifter og praksis-materiale samt andre kildetyper. Hver kildetype har sine styrker og sine svagheder. I en kombination bliver de særdeles værdifulde. Dette gælder også for områder, hvor der er en udbredt anvendelse af tabeller og takster, for eksempel bødeområdet for en række særlovsovertrædelser.

\subsection{Hvilken myndighed skal bestemme over domsbasen?}

For anklagemyndighedens vidensbase, som er et redskab til anklagemyndighedens medarbejdere, er det Rigsadvokaten, som er organisatorisk ansvarlig for vedligeholdelsen af domsbaserne. Rigsadvokaten er samtidig landets vel nok mest specialiserede strafferetsmyndighed, og er som sådan fagligt velegnet til at håndtere opgaven. Rigsadvokaten har også instruktionsbeføjelser over for landets lokale anklagemyndigheder, og har således en god praktisk adgang til at forestå formidlingen af korrekt, relevant praksisviden til landets anklagere.

Indsigelsen mod at lade anklagemyndigheden vedligeholde en vidensbase med retspraksis er, at der er risiko for, at dens indhold bliver »anklagervenligt«, som det så ofte formuleres. Mere principielt består problemstillingen i, at retssystemet på den ene side forfølger et ideal om equality of arms, jf. EMRK art 6, men på den anden side giver anklagemyndigheden en strukturelt yderst favorabel vidensposition. Man kan udstrække synspunktet til at anse det for stærkt betænkeligt, at det er anklagemyndigheden, som har magten over basen, og som indtil videre er den eneste myndighed, som har adgang til indholdet af basen. Grundlæggende er dette en problemstilling, som ikke kan undgås. For det første må man nok konstatere, at den bedste praktiske mulighed for at tilvejebringe nødvendig retlig viden i straffesager i de seneste år har været igennem anklagemyndigheden. I den bedste af mulige verdener har opgaven derfor været at gøre så meget som muligt for, at den strukturelt fordelagtige position, som anklagemyndigheden har, ikke har betydning for indholdet af vidensbasen. Det drejer sig først og fremmest om et stærkt internt redaktionsarbejde med øje for et retvisende praksisniveau. Dernæst drejer det sig om, at Rigsadvokaten løbende kontrollerer alle godkendelser og afvisninger i domsbasen - alle afvisninger skal begrundes. For det andet er det en problemstilling, som nok ikke kunne undgås, fordi vidensbasen sandsynligvis ikke var blevet til, hvis ikke den netop var håndteret som et instrument til at forbedre anklageres arbejdsredskaber. Vidensbasen må således først laves, før den kan udbredes. Udbredelsen til dommere, forsvarsadvokater, forskere og andre kommer til at ske sammen etableringen af den internetforbindelse til politi og anklagemyndighed, som er under udarbejdelse. Dermed får vidensbasen også disse brugergrupper som direkte bedømmere af udvælgelsen af retspraksis. Der er i 
forlængelse heraf mange gode muligheder for i fremtiden, at inddrage såvel forsvarsadvokater som dommere i selve vedligeholdelsen af domsbaserne og deres indhold af retspraksis.

Man kan dog, efter min opfattelse, med god grund forvente, at domstolene i fremtiden kommer til selv at varetage netop denne opgave. Dels er straffens fastsættelse et område, som domstolene traditionelt har et centralt ansvar inden for, dels er det kun domstolene, som repræsenterer den fulde balance i straffeprocessen, og dermed med naturlig autoritet kan præsentere brugere for relevant retspraksis. Dertil kommer, at det, hvis det lykkes domstolene at udvikle en domsbase til at formidle retspraksis $\mathrm{i}$ al almindelighed, vil være administrativt let at udvikle en redaktionel overbygning hertil. I givet fald ville det være naturligt, at Højesteret og de to landsretter bliver organisatorisk involveret $\mathrm{i}$ opgaven, ligesom det ligger ligefor, at både anklagemyndigheden og forsvarerne inddrages i design, vedligeholdelse og udvikling af sådanne domsbaser på det strafferetlige område.

\section{Konkluderende bemærkninger}

Den danske anklagemyndigheds vidensbase og dennes retspraksis bidrager med en forbedret adgang til relevant og vejledende retspraksis for landets anklagere. Og med en direkte internet-adgang til basen også til landets dommere og forsvarere. Det kan med rette forventes, at vidensbasen vil skabe en højere retlig bevidsthed blandt retsanvendere. Om det også afstedkommer et højere retligt niveau og større formel ensartethed i selve afgørelsesvirksomheden afhænger af en række yderligere forhold, herunder særligt byretsdommeres forventninger til den retlige forberedelse og sagsbehandlingens retlige niveau, den ledelsesmæssige ansporing til retlig forberedelse i de lokale anklagemyndigheder, samt den løbende videreuddannelse $\mathrm{i}$ både anklagemyndigheden og ved domstolene.

Anklagemyndighedens vidensbase træder ikke i stedet for eksisterende baser og således ikke i stedet for TfK og UfR. Vidensbasen er et supplement og er konstrueret til at indarbejde de to andre kilders materialer. Ikke desto mindre har udviklingen af anklagemyndighedens vidensbase synliggjort nogle spørgsmål, som såvel eksisterende som nye domsbaser med fordel kan forholde sig til. For det første, at der i enhver domsbase er behov for en bæredygtig balance mellem horisontal og vertikal (hierarkisk) styring. For det andet, at der er store fordele forbundet med at kombinere domsbaser med forskrifter og omvendt. For det tredje spørgsmålet om, hvilke(n) myndighed(er) som skal organisere domsbaser, og hvordan indholdet af domsbaser legitimeres over for de involverede myndigheder. Men vigtigst måske gælder det, at der i dag er for begrænset adgang til byretspraksis på en lang række strafferetsområder, hvor landsretterne ikke har om- 
fattende erfaring, og hvor lokale variationer og særligheder påkalder sig yderligere praksisdækning.

Der er i dag eksempler på yderst avancerede informationssystemer til at assistere ved straffastsættelsen i mange jurisdiktioner. Nederlandene, Canada, Australien (New South Wales), Skotland, Minnesota og Virginia (begge USA) er blot nogle af eksemplerne. Teknikkerne, som anvendes disse steder, er f.eks. statistiske parametre for normalstraffe, percentile fordelinger af sanktionsarter og strafmængder fordelt på gerningstyper og gerningspersoners profiler, samt sammenkobling af ressourcemodeller og strafstørrelser. Det tætteste, man i Danmark har været på sådanne modeller, er nok - udover von Eybens værk »Strafudmåling « fra 1950 - det yderst brugbare bind III til straffelovsrådets betænkning (1424/2002). Men på samme måde som at dette bilag ikke har været anvendt bredt, er det efter min opfattelse tvivlsomt, om anvendelse af statistik (percentiler, middelværdier, gennemsnit) foreløbigt vil finde direkte indpas som standarder for straffastsættelse. Der er megen inspiration at hente fra disse teknikker - i særdeleshed fra det stærke fokus på gennemsnitlige betragtninger og styring gennem midten. Ikke desto mindre bør udviklingen i Danmark efter min opfattelse tage afsæt i de redskaber og det sprog, som retsanvendere benytter, og som har en direkte forbindelse til den retsdogmatiske sammenhæng.

Med dette i hu er der to emner, som har et særligt udviklingspotentiale. Det første er at gøre alle domstoles retspraksis tilgængelig for alle. Det er et projekt, som i mange år har været under forberedelse, og som Domstolsstyrelsen i de seneste år igen har taget aktive skridt til at realisere. De nuværende økonomiske vilkår i retssystemet vil dog sandsynligvis skubbe projektet yderligere ud i fremtiden. I det projekt vil det af pragmatiske grunde give god mening at starte med lands- og Højesteretspraksis, men det er nødvendigt, at basen udvides til også at inkludere byretspraksis så hurtigt som muligt. En almindelig adgang til praksis vil skabe det helt nødvendige grundlag for at kunne udvikle og vedligeholde specialiserede og redigerede domsbaser med tilstrækkelig domspraksis. Det fremhæves til tider som argument imod en almindelig domsbase og imod at inkludere byretspraksis i den, at mængden af afgørelser vil forvirre snarere end vejlede. Det er ikke et holdbart argument og blander tilgængelighed sammen med redaktionel udvælgelse. En videre udvælgelse vil selvfølgelig skulle foretages, men dels er offentlig adgang til retspraksis et formål i sig selv (Gøtze og Olsen 2010), dels er forudsætningen for en brugbar udvælgelse at samtlige domme er tilgængelige. Med udgangspunkt i en sådan almindelig domsbase og let tilgængelighed af retspraksis kan man herefter forestille sig en eller flere overbygninger af specialise- 
rede og redigerede baser, som vejleder dommere, anklagere og forsvarer i, hvordan straffen fastsættes inden for udvalgte strafferetlige områder.

Den anden udviklingsmulighed vedrører viden om sanktionsarter og deres anvendelse. I stedet for at forøge struktureringen og kategoriseringen af den dømtes personlige forhold, kan man forøge den tilgængelige viden om de enkelte sanktionsformer og deres abstrakte og konkrete brugbarhed. Der er f.eks. meget sparsom adgang til viden om, hvilke vilkår som kan knyttes til en betinget straf, den faktiske adgang til at anvende de enkelte vilkår, samt hvad der ville komme ud af at anvende de enkelte vilkår overfor en bestemt person. Al den stund at en stor del af de sanktioner, som anvendes ved domstolene, har deres rationale $\mathrm{i}$ individualpræventive formål, er det påfaldende, hvor lidt viden den enkelte retsanvender har til rådighed herom. Man kunne i fremtiden forestille sig, at vidensystemer (domsbaser) ikke kun giver oplysninger om gerningen og personen og så den straf, som almindeligvis gives, men også supplerer relevant retspraksis inden for et givent emne med oplysninger om de berørte sanktionstyper, hvilke der er adgang til, samt hvad prospektet er for en personprofil som den dømte ved anvendelsen af en bestemt sanktionsart.

\section{Noter}

1. Jeg takker Charlotte Lauritsen for uvurderlige kommentarer til et foreløbigt manuskript, samt redaktøren og den anonyme reviewer for meget konstruktive bemærkninger.

2. Forfatteren er cand. jur., ph.d. og videnchef hos Rigsadvokaten, hvorfra han har orlov fra september 2011. Han er samtidig Research Fellow ved det juridiske fakultet, Lunds Universitet. Synspunkterne i artiklen er forfatterens egne og kan ikke henføres til Rigsadvokaten.

3. Se herom blandt andet Elholm (2010) og Therkelsen (2011).

4. Det følger af retsplejelovens $\S 902$, at anklagemyndigheden kun kan anke, hvis der »efter loven kan idømmes andre offentligretlige følger end bøde eller konfiskation for lovovertrædelsen.« Det følger endvidere, at tiltalte som udgangspunkt kun kan anke, når tiltalte whar givet møde i byretten og er idømt 1) mere end 20 dagbøder, 2) en bøde på over 3.000 kr., 3) konfiskation af genstande af tilsvarende værdi eller 4) andre offentligretlige følger«. Efter $\S 903$ kan procesbevillingsnævnet derudover tillade anke hvis sagen er af principiel karakter eller særlige grunde i øvrigt taler for det. Se i det hele retsplejelovens $\S \S 902-903$.

5. F.eks. tematisk afgrænsede dokumenter, som samler forskellige former for praktisk viden og linker videre til interne så vel eksterne kilder.

6. Adgangen til Karnov Group og biblioteksbasen er etableret fuldt ud for så vidt angår anklagerne i politikredsene. I skrivende stund er adgangen ved at blive færdigetableret for anklagerne ved statsadvokaturene og hos rigsadvokaten.

7. Det er således en realitet i dagligdagen, at kollegaen er en af de vigtigste kilder til relevant faglig viden for mødende anklagere. Det skyldes dels, at meget relevant viden ikke lader sig nedskrive, dels at meget viden helt naturligt lagres i institutionen og hos dens medarbejdere. Pointen med at integrere kontaktoplysninger på kolleger i vidensbasen er at gøre 
denne viden tilgængelig på tværs af embeder, sammen med de mere traditionelle forskrifter og retspraksis, som vi plejer at søge efter. Denne del af vidensbasen er ikke implementeret endnu.

8. Udviklingen af vidensbasens emnestruktur har været et større selvstændigt projekt. Med udgangspunkt $\mathrm{i}$ et udkast, udarbejdet på grundlag af eksisterende emnetaksonomier samt eksisterende materiale ved domstolene og i anklagemyndigheden, udarbejdedes en samlet emnetaksonomi gennem et antal workshops med medarbejdere fra anklagemyndighedens embeder. Produktet blev gennemgået og redigeret af Rigsadvokaten og anvendt som grundlag for vidensbasen.

9. Det sker typisk ved den store gennemgang hver 2-3 år, eller umiddelbart i forlængelse af praksisændringer fra Højesteret.

10. De første år har der været en stadigt stigende overensstemmelse mellem de normerede og de faktisk indsendte. Det landsdækkende faglige ledelsesforum har løbende fulgt op på implementeringen.

11. Om denne sondring, se til sammenligning Duffs (2005) sondring mellem numerisk (Benthamsk) og diskursiv (Aristotelisk) vejledning i straffastsættelsen.

12. Heri ligger en diskussion, som ligger uden for artiklens område. Se nærmere Zahle (2005, 67-91) samt Therkelsen (2011).

13. Se højesteretsdommene U2010.2548H, U2010.2552H, U2011.494H, U2011.498H, U2011.502H og U2011.504H.

\section{Referencer}

Elholm, T., 8:13 om bøder og proportionalitet i specialstrafferetten. Jurist- og økonomforbundets forlag. København. 2010.

Duff, A., »Guidance and Guidelines« in Columbia Law Review. Vol 105: 1162-1189, 2005.

Frase, R. »Punishment Purposes« in Stanford Law Review. Vol. 58:67-83, 2005.

Greve, V., Straffene, 2. udgave, Jurist- og Økonomforbundets Forlag, 2002.

Gøtze, M. og Olsen, H. P., »Offentliggørelse af domme« i Ugeskrift for Retsvæsen, B, side 7180,2010 .

Hutton, N., Tata, C., Wilson, J., N. »Sentencing and Information Technology: Incidental Reform? « i International Journal of Law and Information Technology, vol 2. No. 3, 1994.

Justitsministeriet. Straffeloverådets kommissorium om visse spørgsmål om regulering af strafniveauer for bestemte lovover-trcedelser, herunder brug af minimumsstraf, 14. august 2009.

Nordisk Strafferettskomité, Straffutmåling. Betenkning NU 1984:2. Helsingfors. 1983.

Ostrom, B., Ostrom, C., Hanson, R., Kleinmann, M. Assessing Consistency and Fairness in Sentencing: A comparative study in three states. National Centre for State Courts. 2008.

Therkelsen, Christian Poul Vegger. Lovmotivers strafudmålingsanvisninger. Speciale. Det Juridiske Fakultet, Københavns Universitet. 2011.

Tonry, M. Sentencing Matters. Oxford University Press. 1996.

Tonry, M. 2001. »Punishment Policies and Patterns in Western Countries« in Tonry, M. and Frase, R. (eds.) Sentencing and Sanctions in Western Countries, Oxford University Press, 2001.

Wandall, Rasmus H. »Actuarial Risk Assessment. The Loss of Recognition of the Individual Offender« i Law, Probability, and Risk. Vol. 5, 175-200, 2006. 
Rasmus H. Wandall

Von Eyben. E. Strafudmåling. København. 1950.

Waaben, Knud, Strafferettens almindelige del II. Sanktionslaeren. 5. Udgave. Forlaget Thomson. København. 2001.

Zahle, H. Praktisk Retsfilosofi. Christian Ejlers' Forlag. København. 2005. 